Z. Klin. Chem. Klin. Biochem.

13. Jg. 1975 , S. 553-562

\title{
Absorption of Short and Medium Chain Fatty Acids in the Jejunum of the Rat
}

\author{
By Christine Naupert and K. Rommel \\ Department of Clinical Chemistry of the University of Ulm
}

(Eingegangen am 19. April/11. Juli 1975)

Summary: The uptake of the shortest six fatty acids (acetic to octanoic) was studied in vitro, using everted segments of rat jejunum. The marked influence of medium-pH and fatty acid chain-length suggests that non-ionic diffusion through the lipoid membrane is quantitatively the most important way of transport, but ionic diffusion through the membrane as well as transport through hydrophilic pores also seem to play a role. Though fatty acids evidently are accumulated in the tissue-fluid, and saturation kinetics, competitive inhibition and sodium- as well as energy-dependence apparently are observed, the transport mechanism is assumed to involve solely passive diffusion, - the concept of a carrier-mediated transport for short and medium chain fatty acids seems improbable.

\section{Resorption kurz- und mittelkettiger Fettsäuren im Jejunum der Ratte}

Zusammenfassung: In in vitro-Versuchen mit evertierten Segmenten des Jejunums der Ratte wurde die Aufnahme der sechs kürzesten Fettsäuren (Essigsäure bis Oktansäure) untersucht. Der deutliche Einfluß des pH-Wertes des Mediums und der Kettenlänge der Fettsäuren läßt den Schluß zu, daß die nicht-ionische Diffusion durch die Lipidmembran den quantitativ wichtigsten Transportmechanismus darstellt. Dem Ionentransport durch die Membran und dem hydrophilen Porentransport ist jedoch ebenfalls Bedeutung zuzumessen. Obwohl eine deutliche Akkumulation der Fettsäuren in der Gewebsflüssigkeit gemessen wurde, sowie Sättigungskinetik, kompetitive Hemmung, Energie- und Natrium-Abhängigkeit nachweisbar waren, wird der Fettsäuretransport allein auf passive Diffusion zurückgeführt. Die Annahme eines carriervermittelten Transportmechanismus scheint unbegründet.

\section{Introduction}

There are three possible routes for the passage of a substance through the lipoid membrane of the small intestinal mucosa:

1) the hydrophilic route

2) the carrier-mediated route

3) the lipophilic route

The hydrophilic route, i.e. passage through water-filled pores, is available only for smaller molecules not exceeding a molecular weight of about 150 , whereby not only the size and shape of the molecule are important, but also its charge and state of hydration.

The transport of many hydrophilic substances too large to pass through pores is assumed to occur by means of substrate specific carriers (facilitated transport). A carrier-mediated transport dependent on metabolic energy is referred to as an "active transport". In this case substrate may accumulate within the cell, it may be absorbed against a chemical or electrical gradient.
Saturation kinetics, sodium dependence and competitive substrate inhibition are further characteristics of carrier-mediated transport systems.

The lipophilic route is of importance for all non-polar substances, as these are able to diffuse through the cell membranes due to their lipid solubility.

A special case of lipophilic transport is described by the "pH-partition hypothesis" $(1,2,3)$ which applies to the transport of weak electrolytes in general. This hypothesis is based on the prerequisite that the $\mathrm{pH}$ of the water-solution - and thus the degree of substrate ionisation on one side of the separating lipid-membrane is different from that on the other side, further, that the lipidmembrane is permeable mainly for the undissociated molecules (theory of non-ionic diffusion). At equilibrium, when the concentration of undissociated molecules is equal on both sides of the membrane, there will be a higher total substrate concentration (undissociated molecules and substrate-ions) within the compartment with the higher $\mathrm{pH}$. 
Whereas it is generally assumed that long-chain fatty acids primarily are absorbed through the mucosal membrane by way of the lipophilic route (4) there has been some controversy in the literature considering the way of transport of short and medium chain fatty acids $(5-10)$. These acids are relatively small molecules having both hydrophilic and lipophilic characteristics. Thus all three of the mentioned ways of transport could be involved in the SCFA ${ }^{1}$ ) and MCFA ${ }^{1}$ ) absorption.

This study is concerned with the relative importance of the mentioned transport mechanisms for the uptake of short and medium chain fatty acids from the jejunal lumen into the mucosal cell.

The following aspects were considered:

1. influence of the intestinal location

2. uptake rate

3. fatty acid efflux

4. factors that influence passive diffusion:

a) influence of the chain-length

b) influence of the medium-pH

5. criteria for "active" carrier-mediated transport:

a) uptake against a concentration gradient

b) influence of medium-concentration (saturation kinetics)

c) competitive inhibition

d) dependence on energy

\section{Material and Methods}

\section{Substances}

Fatty acids

Acetic acid $\left(C_{2}\right)$, p.a. Merck; propionic acid $\left(C_{3}\right)$, puriss., Serva; butyric acid $\left(\mathrm{C}_{4}\right)$, puriss., Fluka; pentanoic acid $\left(\mathrm{C}_{5}\right)$, p.a. Merck; hexanoic acid $\left(\mathrm{C}_{6}\right)$, puriss., Fluka; heptanoic acid $\left(\mathrm{C}_{7}\right)$, p.a. Merck; octanoic acid $\left(\mathrm{C}_{8}\right)$, puriss., Serva; sodium propionate, sodium butyrate, sodium heptanoate and sodium octanoate: all puriss., Serva.

\section{Radioactive substances}

sodium $\left[1-{ }^{14} \mathrm{C}\right]$ ace tate, sodium $\left[1-{ }^{14} \mathrm{C}\right]$ propionate, sodium $\left[1-{ }^{14} \mathrm{C}\right]-$ butyrate, sodium $\left[1{ }^{14} \mathrm{C}\right]$ pentanoate, sodium $\left[1-{ }^{14} \mathrm{C}\right]$ hexanoate, sodium $\left[1-{ }^{14} \mathrm{C}\right]$ heptanoate, sodium $[1-14 \mathrm{C}]$ octanoate, $\left[1-{ }^{14} \mathrm{C}\right] D$ galactose, $\left[1-{ }^{14} \mathrm{C}\right] D$-glucose, all from the Radiochemical centre, Amersham, England; inulin $\left({ }^{14} \mathrm{C}\right)$-carboxyl, from Buchler \& $\mathrm{Co}$, Mannheim.

\section{Other substances}

Ouabain (g-strophanthine), p.a., Merck; 2,4-dinitrophenol, p.a., Merck; soluene TM 100, Packard, Frankfurt/M.; PPO (2.5-diphenyloxazol), p.a., Merck; toluene, p.a., Merck, 3-oxymethyl glucose, p.a., Merck.

\section{Solutions}

\section{Buffer solutions}

1) Krebs-Ringer-phosphate buffer, modified:

$0.154 \mathrm{~mol} / 1 \mathrm{NaCl}, 0.154 \mathrm{~mol} / 1 \mathrm{KCl}, 0.154 \mathrm{~mol} / 1 \mathrm{KH}_{2} \mathrm{PO}_{4}$, $0.1 \mathrm{~mol} / 1 \mathrm{Na}_{2} \mathrm{HPO}_{4}$.

\footnotetext{
1) Uncommon abbreviations:

SCFA - short chain fatty acids

MCFA - medium chain fatty acids

LCFA - long chain fatty acids

ECS - extra-cellular space
}

2) Citrate-phosphate-buffer, modified:

$0.1 \mathrm{~mol} / 1 \mathrm{citric}$ acid, $0.2 \mathrm{~mol} / 1 \mathrm{Na}_{2} \mathrm{HPO}_{4}, 0.13 \mathrm{~mol} / 1 \mathrm{KCl}$.

The amounts of the above mentioned solutions varied according to the required fatty acid concentration and the $\mathrm{pH}$ of the medium. The final sodium concentration was adjusted to 145 $\mathrm{mmol} / \mathrm{l}$; the potassium concentration to $13 \mathrm{mmol} / \mathrm{l}$; and the osmolarity to $300 \mathrm{mosmol} / \mathrm{l}$.

Liquid scintillation solution

PPO (2.5-diphenyloxazole) in toluene $(5 \mathrm{~g} / 1)$ '

\section{Instruments}

Liquid scintillation counter "Tri Carb", model 3380 (Packard, Frankfurt/M); shaking water-bath (Braun-Melsungen); $\mathrm{pH}$-meter TTT 1 c (Radiometer, Copenhagen); semi-micro-osmometer (Knauer, Berlin); analytical balance "H 20 T" (Mettler, Zürich); flame photometer with internal lithium standard, (PerkinElmer/Überlingen); thermostate 3401 (Eppendorf/Hamburg).

\section{Tissue preparations}

Male, -originally SPF (specific pathogen free) -Wistar-rats ("FW 49 "), $220 \mp 20 \mathrm{~g}$, from Thomae, Biberach/Riss, were fasted $24 \mp 4$ hours prior to cervical dislocation. The jejunum $(10-55 \mathrm{~cm}$ from the pylorus) was removed, flushed with $9 \mathrm{~g} / \mathrm{l}$ sodium chloride solution, everted and washed in buffer solution. Care was taken to eliminate "Payer's patches". $0.5 \mathrm{~cm}$ segments, "open segments", or $1 \mathrm{~cm}$ segments for incubation in the tissue-holding apparatus according to Semenza (12) were prepared. In one case (inhibition with ouabain) sac preparations (13) were used.

\section{Procedure}

After adjustment of the different incubation media to the required concentration, $\mathrm{pH}$ and osmolarity, radioactive fatty acids in tracer amounts $(0.1-0.2 \mathrm{mCi} / \mathrm{l})$ were added. The solutions were in every case clear (no emulsions). For measurement of total radioactivity $0.1 \mathrm{ml}$ samples of the media were dissolved in $1 \mathrm{ml}$ soluene (triplicate determinations) and counted 5 . $\min$ in toluene scintillation liquid.

The "open segments" were incubated in duplicate in $2 \mathrm{ml}$ of pregassed medium at $37^{\circ} \mathrm{C}$. All glasses in the shaking waterbath werc gassed once more with oxygen and closed with rubber caps. After incubation the segments were "dried" between moistened filter paper, weighed, dissolved overnight at $37^{\circ} \mathrm{C}$ in $1 \mathrm{ml}$ soluene and, after addition of $12 \mathrm{ml}$ scintillation liquid, counted in the Tri Carb for $5 \mathrm{~min}$.

In most experiments the tissue preparation according to Semenza was used, i.e. "clamped segments" thereby avoiding any sideeffects by absorption or loss from the serosal side of the tissue. Three segments werc incubated at a time in $25 \mathrm{ml}$ beakers containing $10 \mathrm{ml}$ pregassed medium. During the incubation in the shaking water-bath at $37^{\circ} \mathrm{C}$ the tissues were gassed with oxygen, then quickly removed and rinsed in ice-cold buffer, "dried", weighed, dissolved in soluene, and counted as described above.

\section{Calculation of fatty acid absorption}

In accordance with Crane \& Mandelstain (14) the increase of radioactivity was expressed as the fatty acid concentration of the tissuc fluid in percentage of the total fatty acid concentration of the original incubation medium, assuming that the tissue fluid cquals 80 per cent of the tissue wet weight:

$$
\text { "per cent absorption": } \begin{aligned}
& \frac{\mathrm{cpm}_{(\mathrm{FA})} / \text { tissue fluid }}{\mathrm{cpm}_{(\mathrm{FA})} / \mathrm{ml} \text { incubation medium }} \times 100 \\
& =\frac{\mathrm{cpm}_{(\mathrm{FA})} / 0.8 \times \text { tissue wet weight }(\mathrm{g})}{\mathrm{cpm}_{(\mathrm{FA})} / \mathrm{ml} \text { incubation medium }} \times 100
\end{aligned}
$$

$\mathrm{FA}=$ fatty acid

Determination of the mucosal extracellular space $(E C S)^{1}$ )

For the measurement of the mucosal extracellular space tissue samples were incubated simultaneously and in an cqual manner as described above in ${ }^{14} \mathrm{C}$-inulin-containing media. 


$$
\text { aCS: } \frac{\mathrm{cpm}_{(\text {inulin) }} / \mathrm{ml} \text { tissue fluid }}{\mathrm{cpm}_{(\text {inulin })} / \mathrm{ml} \text { incubation medium }} \times 100
$$

The determination of the mucosal ECS was performed in all experiments using the "Semenza-technique".

\section{Determination of fatty acid efflux}

Efflux experiments were performed with tissue samples incubated $5 \mathrm{~min}$ in the tissue-holding apparatuses at different concentrations and $\mathrm{pH}$-values. Thereafter one third of the samples (I) were briefly rinsed three times in $9 \mathrm{~g} / 1$ sodium chloride solution and "dried". One third (II) was incubated once more 5 $\mathrm{min}$ in the same medium, then rinsed and "dried" as described above. One third (III) was rinsed as above and incubated for another $5 \mathrm{~min}$ in fatty acid-free medium, thereafter rinsed and "dried".

For the determination of the efflux-rate the tissue samples were briefly rinsed after incubation ( 3 or $10 \mathrm{~min}$ ) and incubated in fatty acid-frec medium for another $2,4,6,8$ or $10 \mathrm{~min}$.

\section{Statistics ${ }^{2}$ )}

The following statistical methods were used:

1) calculation of the mean $(\bar{x})$, standard deviation (s) and standard error of the mean (SEM);

2) Student-t-test for paired samples;

3) :malysis of variance: a) four-tvay analysis, model 1, crossed b) two-way analysis, model I. crossed

\section{Results}

Fatty acid absorption in different small-intestinal sections

In experiments with propionic acid it was shown that the absorption differed, depending on the intestinal section chosen, when a medium-pH of 7 was used, but not in a medium of $\mathrm{pH} 5$ (tab. 1). An equivalent experiment with octanoic acid at $\mathrm{pH} 4.0$ showed no absorption differences in different sections.

\section{Fatty acid uptake-rate}

In two experimental series, using the "Semenza-technique", the uptake of propionic $\left(\mathrm{C}_{3}\right)$ and octanoic $\left(\mathrm{C}_{8}\right)$ acids was determined at short time intervals. As shown in figure 1 and 4 the uptake proceeds very quickly within the first two minutes, approaching linearity between about 2 and $8 \mathrm{~min}$, thereafter falling off gradually.

Tab. 1. Absorption capacity of different sections of the small intestinc. Clamped segments in citrate-phosphatc-buffer. 3 min. $\mathrm{n}=12 . \overline{\mathrm{x}} \mp \mathrm{SEM}$

\begin{tabular}{llll}
\hline & $\begin{array}{l}\text { cm behind } \\
\text { pylorus }\end{array}$ & $\begin{array}{l}\text { percent } \\
\text { filling }\end{array}$ & $\begin{array}{l}\text { percent of } \\
\text { section 1 }\end{array}$ \\
\hline Exp. 1 & $10-25$ & $56.7 \pm 4.9$ & \\
propionic acid & $40-60$ & $52.9 \pm 7.2$ & 93.3 \\
5 mmol/1, pH 5 & $75-90$ & $57.1 \pm 4.5$ & 100.7 \\
& & & \\
Exp. 2 & $10-25$ & $32.3 \pm 4.2$ & \\
propionic acid & $40-60$ & $27.3 \pm 1.4$ & 84.5 \\
5 mmol/1, pH 7 & $75-90$ & $24.7 \pm 4.1$ & 76.5 \\
\hline
\end{tabular}

2) The statistical methods were planned and evaluated by Dr. $W$. Gaus, Dept. of Medical Statistics, Documentation and Data Processing, University of Ulm.

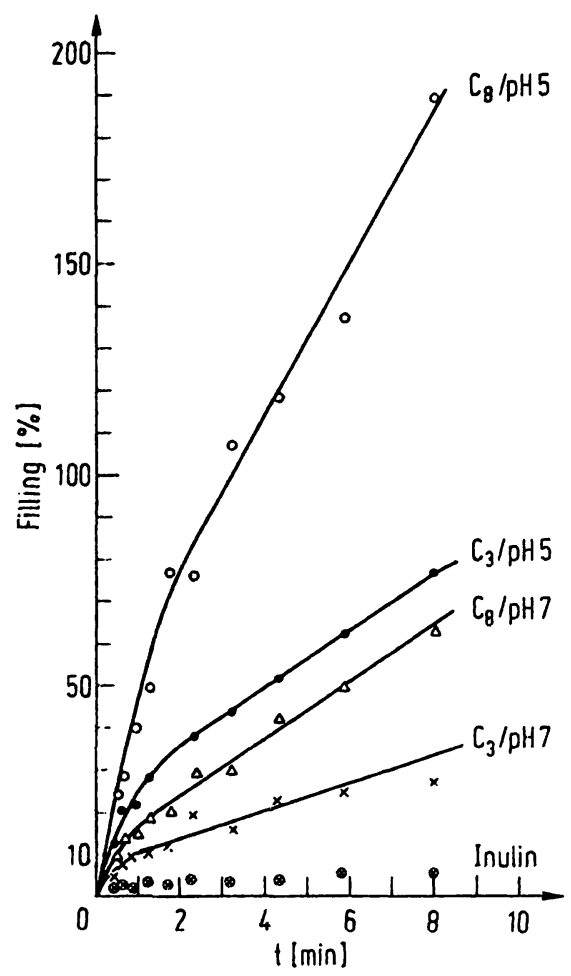

Fig. 1. Fatty acid uptake vs. time.

$5 \mathrm{mmol} / \mathrm{l}$ citrate-phosphate-bufter, clamped segments. $n=2$.

\section{Fatty acid efflux}

The results of the efflux-experiments are listed in table 2. This table shows also the relative increase and decrease of fatty acid concentration between 5 and 10 min ("influx": II-I, "efflux": I-III). No regular relatonship is seen between per cent increase and decrease However, it can be seen that the relation $\frac{\mathrm{I}+\mathrm{III}}{\text { II }}$ in all
cases approaches the value 1.0 .

This is also illustrated in figure 2.

The efflux-rate as a function of tissue concentration and fatty acid chain-length is illustrated in figure 3.

\section{Factors that influence passive diffusion}

In two systematic experimental series using "open segments", the absorption of several fatty acids was measured at different medium-pH, different concentrations and - in series I - at different incubation times.

\section{Series I:}

fatty acids: $\mathrm{C}_{3}, \mathrm{C}_{4}, \mathrm{C}_{7}$ and $\mathrm{C}_{8}$

$\mathrm{pH}: 4.0,5.5,7.0$

concentration: 0.5 and $5.0 \mathrm{mmol} / \mathrm{l}$

incubation time: $3,9,15$ and $60 \mathrm{~min}$

\section{Series II:}

fatty acids: $\mathrm{C}_{2}, \mathrm{C}_{3}, \mathrm{C}_{4}, \mathrm{C}_{5}, \mathrm{C}_{6}, \mathrm{C}_{7}, \mathrm{C}_{8}$ $\mathrm{pH}: 4.0,6.3,8.6$

concentration: 0.5 and $5.0 \mathrm{mmol} / \mathrm{l}$

incubation time: $3 \mathrm{~min}$. 
Tab. 2. Efflux as a function of $\mathrm{pH}$, chain-length and concentration. Percent filling: $\bar{x} \mp$ SEM

\begin{tabular}{|c|c|c|c|c|}
\hline & $n$ & $5 \min (I)$ & $10 \min (I I)$ & $5+5 \min (I I I)$ \\
\hline $\begin{array}{l}\mathrm{C}_{3}, 5 \mathrm{mmol} / \mathrm{l}, \mathrm{pH} 5 \\
\mathrm{C}_{3}, 50 \mathrm{mmol} / \mathrm{l}, \mathrm{pH} 5 \\
\mathrm{C}_{3}, 5 \mathrm{mmol} / \mathrm{l}, \mathrm{pH} 7 \\
\mathrm{C}_{3}, 50 \mathrm{mmol} / \mathrm{l}, \mathrm{pH} 7\end{array}$ & $\begin{array}{l}7 \\
7 \\
8 \\
7\end{array}$ & $\begin{array}{l}44.8 \pm 4.8 \\
29.7 \pm 3.7 \\
19.8 \pm 1.4 \\
18.1 \pm 2.2\end{array}$ & $\begin{array}{l}61.4 \pm 3.3 \\
37.3 \pm 2.9 \\
28.4 \pm 2.8 \\
23.3 \pm 2.6\end{array}$ & $\begin{array}{r}21.8 \pm 2.6 \\
14.1 \pm 1.7 \\
6.0 \pm 0.7 \\
5.0 \pm 0.9\end{array}$ \\
\hline \multirow[t]{2}{*}{$\begin{array}{l}\mathrm{C}_{8}, \quad 5 \mathrm{mmol} / \mathrm{l}, \mathrm{pH} 5 \\
\mathrm{C}_{8}, 20 \mathrm{mmol} / \mathrm{l}, \mathrm{pH} 5 \\
\mathrm{C}_{8}, 5 \mathrm{mmol} / \mathrm{l}, \mathrm{pH} 7 \\
\mathrm{C}_{8}, 20 \mathrm{mmol} / \mathrm{l}, \mathrm{pH} 7\end{array}$} & $\begin{array}{l}11 \\
12 \\
16 \\
16\end{array}$ & $\begin{array}{l}97.6 \pm 7.2 \\
98.0 \pm 6.0 \\
35.5 \pm 3.4 \\
29.6 \pm 1.7\end{array}$ & $\begin{array}{rr}171.7 & \pm 8.1 \\
159.3 & \pm 11.2 \\
47.6 & \pm 2.6 \\
39.1 & \pm 1.7\end{array}$ & $\begin{array}{l}73.5 \pm 4.8 \\
62.1 \pm 4.8 \\
16.1 \pm 1.6 \\
12.9 \pm 1.1\end{array}$ \\
\hline & $\begin{array}{l}\text { influx } \\
\text { (II-I) } \\
\% \\
\end{array}$ & $\begin{array}{l}\text { efflux } \\
\text { (I-III) } \\
\% \\
\end{array}$ & $\frac{\text { percent increase }}{\text { percent decrease }}$ & $\frac{I+I I I}{I I}$ \\
\hline $\begin{array}{l}\mathrm{C}_{3}, 5 \mathrm{mmol} / \mathrm{l}, \mathrm{pH} 5 \\
\mathrm{C}_{3}, 50 \mathrm{mmol} / \mathrm{l}, \mathrm{pH} 5 \\
\mathrm{C}_{3}, 5 \mathrm{mmol} / \mathrm{l}, \mathrm{pH} 7 \\
\mathrm{C}_{3}, 50 \mathrm{mmol} / \mathrm{l}, \mathrm{pH} 7\end{array}$ & $\begin{array}{r}16.6 \\
7.6 \\
8.6 \\
5.2\end{array}$ & $\begin{array}{l}23.0 \\
15.6 \\
13.8 \\
13.0\end{array}$ & $\begin{array}{l}0.72 \\
0.49 \\
0.62 \\
0.40\end{array}$ & $\begin{array}{l}1.08 \\
1.17 \\
0.91 \\
0.99\end{array}$ \\
\hline $\begin{array}{l}\mathrm{C}_{8}, \quad 5 \mathrm{mmol} / 1, \mathrm{pH} 5 \\
\mathrm{C}_{8}, 20 \mathrm{mmol} / 1, \mathrm{pH} 5 \\
\mathrm{C}_{8}, 5 \mathrm{mmol} / 1, \mathrm{pH} 7 \\
\mathrm{C}_{8}, 20 \mathrm{mmol} / 1, \mathrm{pH} 7\end{array}$ & $\begin{array}{r}74.1 \\
61.3 \\
12.1 \\
9.5\end{array}$ & $\begin{array}{l}24.1 \\
36.0 \\
19.4 \\
16.7\end{array}$ & $\begin{array}{l}3.08 \\
1.71 \\
0.62 \\
0.57\end{array}$ & $\begin{array}{l}1.00 \\
1.01 \\
1.08 \\
1.09\end{array}$ \\
\hline
\end{tabular}

$\therefore$ :

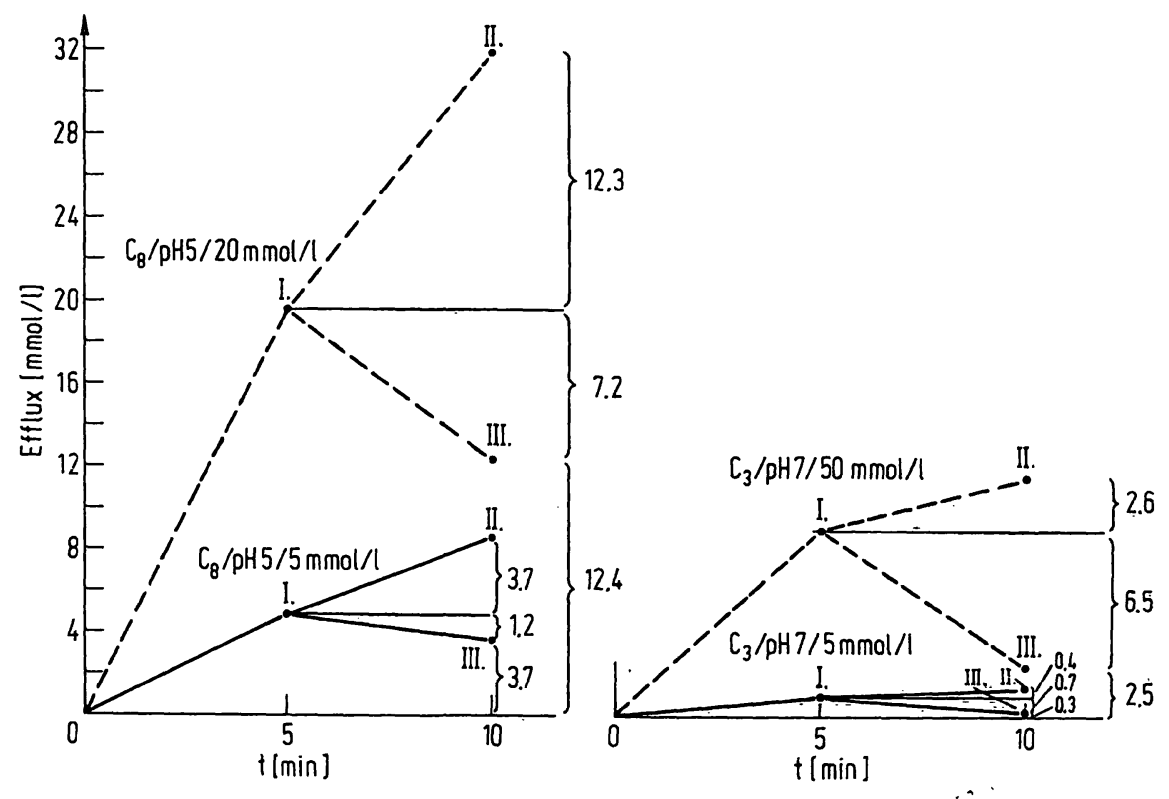

Fig. 2. Measurement of efflux. Clamped segments in citrate-phosphate-buffer. $n=2$.

From analysis of variance it was evident that both the chain-length and the medium-pH significantly influence the degree of absorption ( $\mathrm{p}$ in both cases $\gg 0.99$ ). Further, a significant two-way interaction between the chain-length and medium-pH became apparent ( $\mathrm{p} \gg 0.99)$.

\section{Influence of fatty acid chain-length}

Especially at low pH-values there is seen a considerable effect of the chain-length on fatty acid absorption. For example, (fig. 4) at $\mathrm{pH} 4$ the absorption of octanoic acid $\left(\mathrm{C}_{8}\right)$ reached absorption values about twice as high as those for propionic acid $\left(\mathrm{C}_{3}\right)$. At $\mathrm{pH} 7$ (fig. 5), however, the absorption values of these two acids differed only slightly. In fact, at high medium-pH some short chain fatty acids (SCFA) may even become better absorbed with decreasing chain-length. This interaction between chain-length and medium-pH is clearly illustrated in figure 6, which shows at low $\mathrm{pH}$ an increasing absorp- 

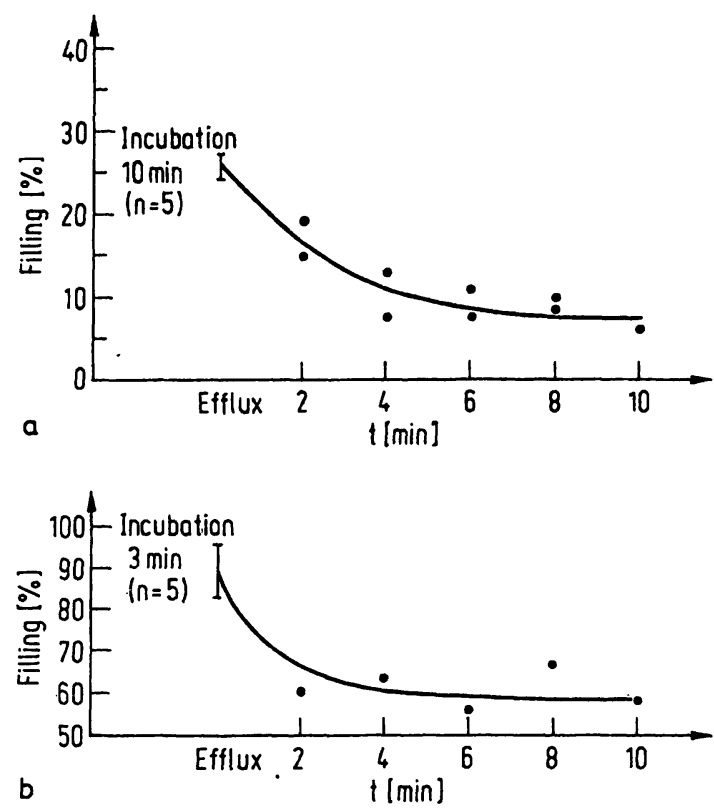

Fig. 3. Efflux vs. time.

Propionic acid $\left(\mathrm{C}_{3}\right), \mathrm{pH} 7$ (a) and octanoic acid $\left(\mathrm{C}_{8}\right)$, pH 5 (b)

Clamped segments in citrate-phosphate-buffer. $n=2$

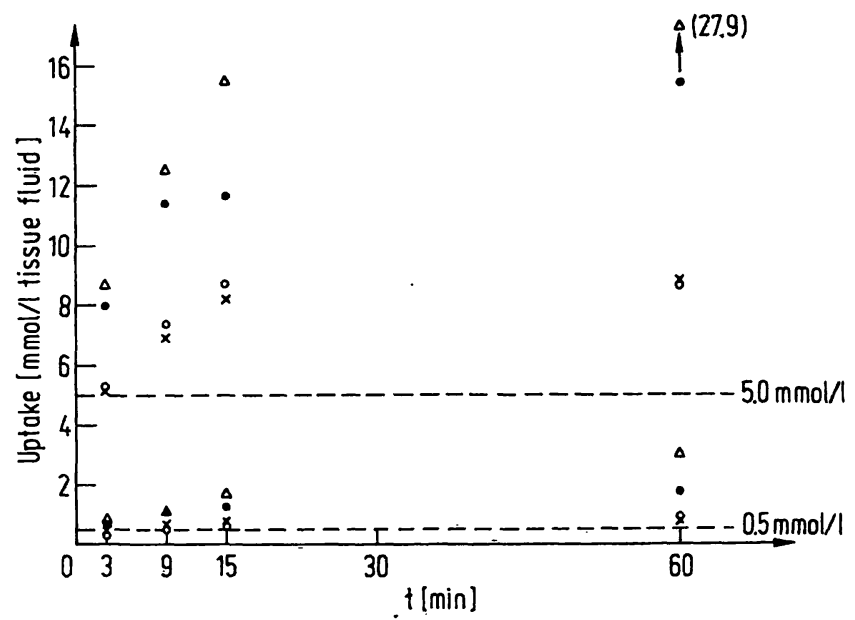

Fig. 4. Fatty acid uptake vs. time

Open segments in Krebs-Ringer-phosphate-bufter, 0.5 and $5.0 \mathrm{mmol} / \mathrm{l}, \mathrm{pH} 4.0 . \mathrm{n}=4$

$\triangle$ octanoic acid (C8)

- heptanoic acid (C7)

- butyric acid (C4)

$\mathrm{x}$ propionic acid (C3)

tion with increasing fatty acid chain-length, while at high $\mathrm{pH}$ there is increasing or equal absorption with decreasing chain-lengths.

\section{Influence of medium-p $\ddot{H}$}

The influence of the medium-pH was in all experiments very obvious: the lower the $\mathrm{pH}$, the higher was the absorption rate (fig. 6);

The influence of the medium-pH on fatty acid absorption was studied further in a systematic experiment

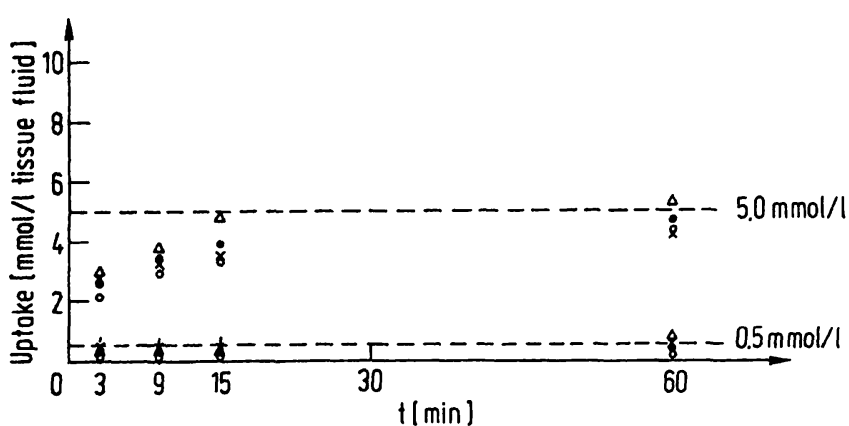

Fig. 5. Fatty acid uptake vs. time

Open segments in Krebs-Ringer-phosphate-buffer, 0.5 and $5.0 \mathrm{mmol} / \mathrm{l}, \mathrm{pH} 7.0 . \mathrm{n}=4$

$\triangle$ octanoic acid (C8)

- heptanoic acid (C7)

o butyric acid (C4)

$x$ propionic acid (C3)

using incubation media between $\mathrm{pH} 4.0$ and 8.0 differing from each other by $0.5 \mathrm{pH}$-units. The results (fig. 7) suggest for octanoic acid a semilogarithmic relationship between absorption and medium-pH (fig. 7). In an identical experiment with propionic acid the semilogarithmic relationship was not as evident.

Criteria for "active" carrier-mediated transport

\section{Uptake against a concentration gradient}

In many experiments it has been shown unequivocally that the fatty acid concentration within the tissue-fluid may greatly exceed that of the medium. For example, the absorption value of octanoic acid at $\mathrm{pH} 4$ after 9 min was more than twice, after 15 min more than three times as high as the medium concentration $(5 \mathrm{mmol} / \mathrm{l})$, (fig. 4).

\section{Influence of medium concentration}

In order to find out whether the fatty acid uptake conforms to "saturation kinetics" several experiments were performed applying increasing concentrations (between 2 and $50 \mathrm{mmol} / \mathrm{l}$ ) of propionic, butyric, heptanoic and octanoic acids. The results (fig. 8-10) indicated that the transport-kinetics do suggest a Michaelis-Menten-type of concentration dependence. The calculated " $\mathrm{K}_{\mathrm{m}}$ "-values in general decreased with increasing fatty acid chainlength and decreasing medium-pH (table 3).

Tab. 3. Influence of fatty acid chain-length and medium-pH on

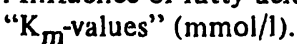

\begin{tabular}{llllll}
\hline & pH S & pH 6 & pH 7 & pH 8 \\
\hline propionic acid $\left(C_{3}\right)$ & 34 & 49 & 74 & - \\
butyric acid $\left(C_{4}\right)$ & - & 37 & - & - \\
heptanoic acid $\left(C_{7}\right)$ & - & 26 & - & - \\
octanoid acid $\left(C_{8}\right)$ & - & 33 & 26 & 36 \\
\hline
\end{tabular}




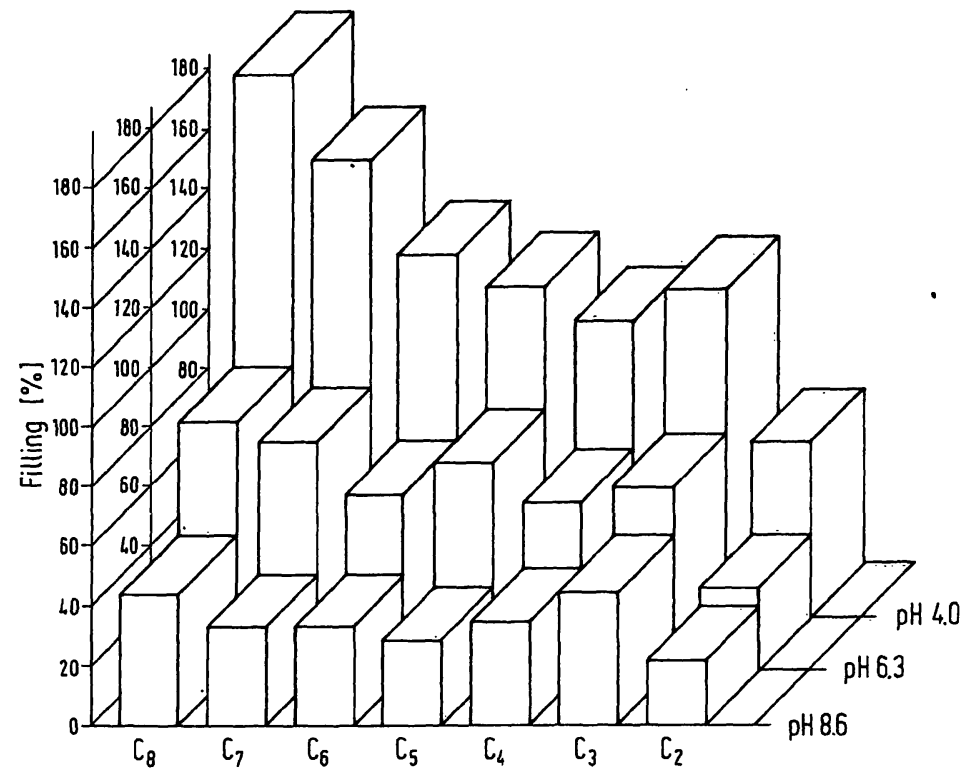

Fig. 6. Interaction between medium-pH and fatty acid chain-length (Series II). $5 \mathrm{mmol} / \mathrm{l}$. Open segments in Krebs-Ringer-phosphatebuffer. 3 min. $n=6$.
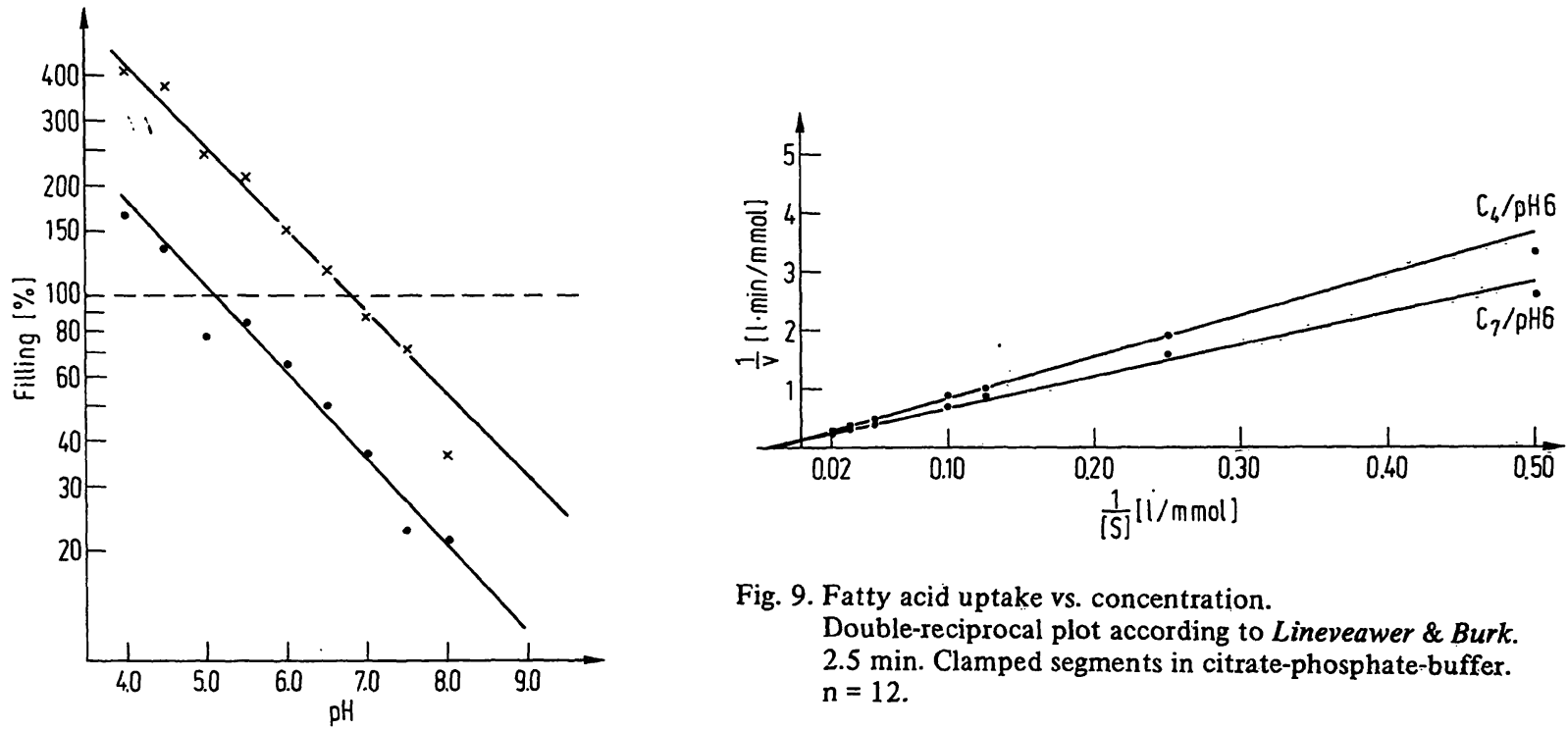

Fig. 9. Fatty acid uptake vs. concentration.

Double-reciprocal plot according to Lineveawer \& Burk. $2.5 \mathrm{~min}$. Clamped segments in citrate-phosphate-buffer. $\mathrm{n}=12$

Fig. 7. Fatty acid uptake vs. medium-pH.

Octanoic acid, $5 \mathrm{mmol} / \mathrm{l}$.

Clamped segments in citrate-phosphate-buffer. $n=2$

$\bullet=2 \min x-x=16 \min$
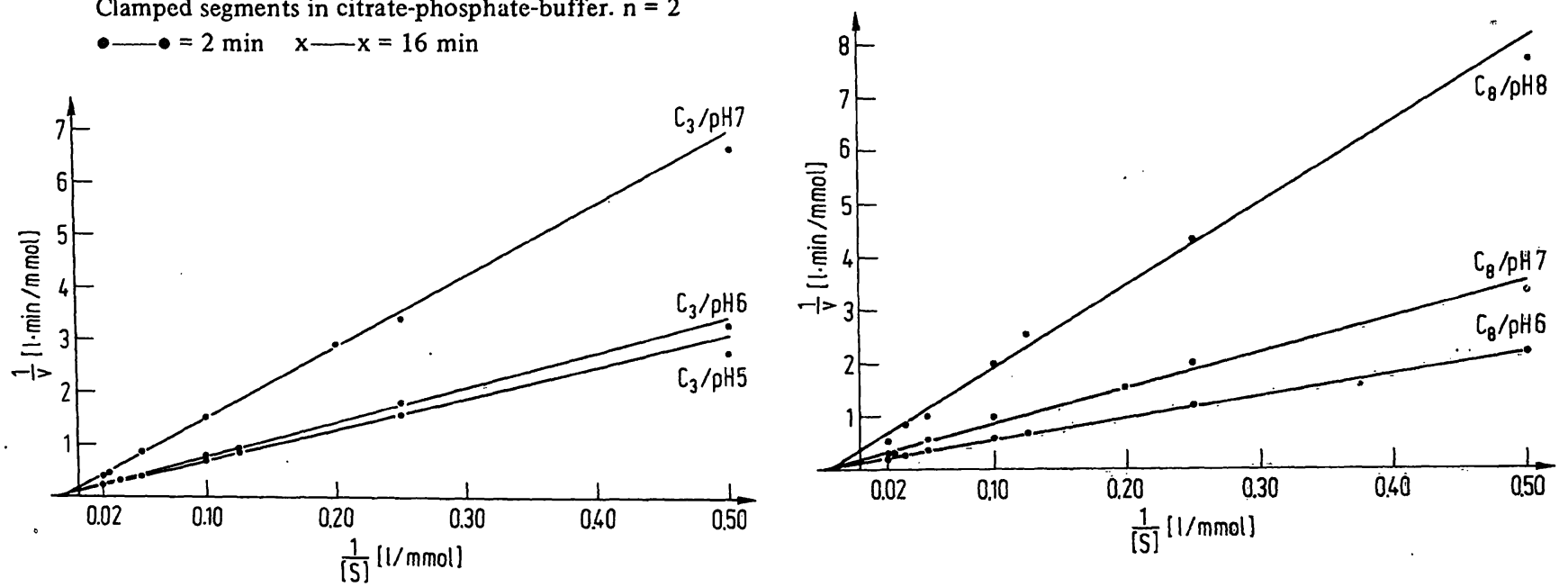

Fig. 8. Fatty acid uptake vs. concentration.

Double-reciprocal plot according to Lineveawer \& Burk. $2.5 \mathrm{~min}$. Clamped segments in citrate-phosphate-buffer. $\mathrm{n}=12$.

Fig. 10. Fatty acid uptake vs. concentration. Double-reciprocal plot according to Lineveawer \& Burk. $2.5 \mathrm{~min}$. Clamped segments in citrate-phosphate-buffer. $\mathrm{n}=12$. 


\section{Competitive inhibition}

As shown in table 4, the experiments in which other SCFA $\left(C_{3}\right)$ or MCFA $\left(C_{7}\right)$ were added to the medium indicated lower absorption of the tested SCFA $\left(\mathrm{C}_{4}\right)$ and MCFA $\left(\mathrm{C}_{8}\right)$, thus suggesting that a competitive inhibition does occur. The inhibition appears to be the more pronounced the longer the chain-length of the inhibiting fatty acid.

\section{Influence of inhibitors of "active" transport}

As a metabolic inhibitor 2.4-dinitrophenol (2.4-DNP) was chosen, as an inhibitor of the "sodium pump" the ATP-ase-inhibiting ouabain was used. Whereas an inhibitory effect on propionic acid uptake was seen in the case of 2.4-DNP, no effect was observed with ouabain (table 5).

Tab. 4. Mutual inhibition of SCFA and MCFA. Clamped segments in citrate-phosphate-buffer. $\mathrm{pH} 6,2.5 \mathrm{~min} . \mathrm{n}=12$

\begin{tabular}{lcc}
\hline & $C_{4}-5 \mathrm{mmol} / \mathrm{l}$ & percent inhibition \\
\hline$+\mathrm{C}_{3}$ & $5 \mathrm{mmol} / \mathrm{l}$ & 0.4 \\
& $10 \mathrm{mmol} / \mathrm{l}$ & 5.0 \\
& $20 \mathrm{mmol} / \mathrm{l}$ & 31.6 \\
& $40 \mathrm{mmol} / \mathrm{l}$ & 36.8 \\
$+\mathrm{C}_{7}$ & $5 \mathrm{mmol} / \mathrm{l}$ & 7.0 \\
& $10 \mathrm{mmol} / \mathrm{l}$ & 11.0 \\
& $20 \mathrm{mmol} / 1$ & 22.2 \\
& $40 \mathrm{mmol} / \mathrm{l}$ & 44.3 \\
& & \\
\hline & $C_{8}-5 \mathrm{mmol} / \mathrm{l}$ & percent inhibition \\
\hline $\mathrm{C}_{3}$ & $5 \mathrm{mmol} / \mathrm{l}$ & 14.2 \\
& $10 \mathrm{mmol} / 1$ & 14.2 \\
& $20 \mathrm{mmol} / 1$ & 15.4 \\
& $40 \mathrm{mmol} / 1$ & 29.6 \\
$+\mathrm{C}_{7}$ & $5 \mathrm{mmol} / 1$ & 26.7 \\
& $10 \mathrm{mmol} / 1$ & 20.8 \\
& $20 \mathrm{mmol} / 1$ & 31.1 \\
& $40 \mathrm{mmol} / 1$ & 43.1 \\
\hline
\end{tabular}

\section{Discussion}

Influence of the intestinal location on the uptake of SCFA and MCFA

It is a well-known fact that absorption processes vary both qualitatively and quantitatively along the small intestine. The reason for this are structural, morphological and functional differences. Not only is the microvillus membrane-area in the jejunum about twice as large as in the ileum (15), but also the pores have been estimated to be much larger in the jejunum than in the ileum. Further, there are changes in the morphology of the mucosa, -e.g. the goblet cells increase distally (16). As to functional differences, it is important to note that there is a spontaneous $\mathrm{H}^{+}$-secretion into the jejunal lumen $(17,3)$, but an increasing bicarbonate-
Tab. 5. Inhibition of "active transport"

a) Inhibition by 2.4.DNP, $5 \mathrm{mmol} / \mathrm{l}$

Clamped segments in citrate-phosphate-buffer; $\mathrm{pH} 5.9$, 20 min., $n=10$, percent filling: $\bar{x} \mp$ SEM.

$\begin{array}{lll}\text { without } & \text { with } & \text { percent } \\ \text { inhibitor } & \text { inhibitor } & \text { inhibition }\end{array}$

propionic acid

$0.5 \mathrm{mmol} / 1 \quad 70.1 \mp 7.8 \quad 30.3 \mp 2.2 \quad 57$

3-0-methyl-

glucose

$0.5 \mathrm{mmol} / \mathrm{l} \quad 63.8 \mp 11.3 \quad 14.0 \mp 0.8 \quad 78$

b) Inhibition by ouabain, $2 \mathrm{mmol} / \mathrm{l}$

Everted sacs in citrate-phosphate-buffer; pH 5.9, 20 min., $n=10$, percent filling: $\bar{x} \mp$ SEM.

$\begin{array}{llll}\text { without } & \text { inhibitor in } & \text { inhibitor in } & \text { inhibitor } \\ \text { inhibitor } & \text { mucosal } & \text { serosal } & \text { in mucosal } \\ & \text { fluid } & \text { fluid } & \text { and serosal } \\ & & & \text { fluid }\end{array}$

propionic

acid

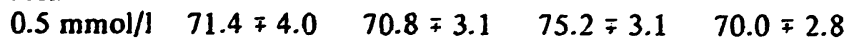

secretion along the ileal lumen. A difference of fatty acid absorption in relation to the small-intestinal section becomes evident only at higher concentrations (18). This fact can probably be interpreted as a result of a gradual approach of the maximum of a limited absorption capacity which differs along the intestine due to the above-mentioned structural and functional differences.

The results with propionic acid (tab. 1) show uptakedifferences in the jejunum and ileum at $\mathrm{pH} 7.0,-$ however, not at $\mathrm{pH} 5$. At the relatively low concentration of $5 \mathrm{mmol} / \mathrm{l}$ apparently an increase of the more diffusible non-ionic form of the fatty acid is sufficient to overcome the limited absorption capacity in the ileum. A corresponding experiment with octanoic acid also showed no topical absorption differences at $\mathrm{pH} 4$.

\section{Influx and efflux}

Both the uptake of fatty acids (influx) and their efflux into substrate-free medium is a very rapid process in the first two minutes, thereafter gradually becoming slower (fig. 1 and 3). Between 2 and $8 \mathrm{~min}$ the uptake-curve seems to be proportional to the incubation-time. The fact that the uptake can be described neither as a purely exponential nor as a purely time-proportional process suggests that several different processes are overlapping.

The rapid uptake and efflux in the very beginning could be due to some unspecific reversible fatty acid binding, e.g. to the glycocalyx or to polar groups of membrane proteins. 
On the other hand it is known from experiments with LCFA that the efflux proceeds in two phases. This observation was interpreted as a process taking place from two different compartments $(19,20)$. Adapting this interpretation, one could assume that the fast uptake in the first few minutes reflects a simultaneous influx into the first and second compartment, whereas the proportional part of the absorption curve is due to a rapid saturation of the first compartment, so that a further influx is possible only at the rate at which substrate diffuses from the first compartment to the second one. The fatty acids in the second compartment are thought to be less easily exchangable (pHeffect?, metabolism?, binding to cell-structures?), which would explain why the fatty acid efflux occurs mainly from the first compartment.

This hypothesis could give an explanation for the mentioned observation (tab. 2, fig. 2) that the relation

$\frac{\text { I }+ \text { III }}{\text { II }}$ in all cases approches 1.0. This fact could also

be expressed as: III = II-I. Both III and II-I stand for the less easily exchangable fatty acids of the second compartment, as the amount of fatty acids that remains in the tissue after the efflux-period (III) equals the amount of those which diffuse from the first to the second compartment (II-I) between the time-interval 5 and $10 \mathrm{~min}$, because the first compartment is already saturated at $5 \mathrm{~min}$. The easily exchangeable fatty acids of the first compartment correspond to I-III.

Due to the given $\mathrm{pH}$-values, it seems probable, that the efflux mainly represents an ion-transport. Thus the hypothetical compartments possibly are identical with different fatty acid transport possibilities through the membrane; the first compartment corresponding to ionic, the second one to non-ionic transfer. A further argument in favour of this explanation is the observation (tab. 2) that the efflux (ion-transport) is relatively less effected by the medium-pH and the fatty-acid chainlength than the influx (non-ionic diffusion + ion-transport).

Fatty acid absorption in relation to chain-length and medium-pH

Though still many questions remain unanswered concerning the structure of the mucosal membrane, Danielli's (21) concept of a lipoprotein-sandwich model (a bimolecular phospholipid layer between two layers of protein), interspersed with proteinous water-filled pores, has been generally accepted.

Therefore, anticipating a passive transfer-mechanism, mainly two factors are decisive for the transport through the cell-membrane:

1) the degree of lipid solubility of lipophilic substrates

2) the effective molecular or ionic size of the hydrophilic substrates
Short and medium chain fatty acids are both lipophilic and hydrophilic. The lipophilic characteristics will increase with increasing chain-length and decreasing degree of ionisation, whereas the hydrophilic characteristics increase with decreasing chain-length.

The results, clearly showing an increased fatty acid uptake with increasing chain-lengths and decreasing medium-pH values, provide considerable support for the view that passive diffusion of the non-ionic molecules plays a predominant role in the uptake process. In addition, the results provide evidence for the alternative diffusion process by way of the route through pores, as at high pH SCFA-absorption increased with decreasing chain-lengths. The fact that the fatty acids at basic or even neutral $\mathrm{pH}$ are practically completely. ionized has probably a favourable effect on the transport through pores, as these are assumed to be positively charged (22).

The relative amounts of the non-ionized and ionized forms of the fatty acids can be calculated from the Henderson-Hasselbalch equation:

$\mathrm{pH}=\mathrm{pK}_{\mathrm{a}}+\log \frac{[\text { salt }]}{\text { [acid] }}$. The $\mathrm{pK}_{\mathrm{a}}$-values of the fatty acids used in these experiments vary only slightly around 4.8 (acetic acid 4.75, octanoic acid 4.89). Thus, for example, at $\mathrm{pH} 4.0$ the percentage of non-ionized molecules is for acetic acid 84.8, for octanoic acid 88.5, whereas at $\mathrm{pH} 7.0$ they are 0.56 and 0.77 , respectively. It is obvious that in neutral or basic solutions, when more than 99 per cent of the acids are in an ionized state, the effect of the chain-length is of minor importance (fig. 6). This explains also, why Barry \& Smyth (6) in their experiments, using a medium-pH of 7.4, could not find any effect of the chain-length on fatty acid uptake.

According to the $\mathrm{pH}$ partition hypothesis the concentration of the fatty acids on the two sides of the lipid membrane is dependent on the $\mathrm{pK}_{\mathrm{a}}$, the $\mathrm{pH}$-values of the solutions on both sides of the separating membrane and on the lipid solubility of the non-ionized molecules. However, it seems likely that at least for the longer members the lipid solubility even of the ions is high enough to permit some ion-transport through the lipidmembrane as well (in fig. 6 uptake of $\mathrm{C}_{8}$ at $\mathrm{pH} 8.6$ in fact does exceed that of $\mathrm{C}_{7}, \mathrm{C}_{6}$ and $\mathrm{C}_{5}$ ).

Not taking the actual lipid solubility of the fatty acid molecules nor the ion-transport, into consideration, the partition of the fatty acids on both sides of the membrane theoretically can be calculated from the following equation, developed by Jacobs (23):

$\frac{\mathrm{C}_{1}}{\mathrm{C}_{2}}=\frac{1+10\left(\mathrm{pH}_{1}-\mathrm{pK}_{\mathrm{a}}\right)}{1+10\left(\mathrm{pH}_{2}-\mathrm{pK}_{\mathrm{a}}\right)}$. Though this equation cannot be applied directly, as actually both differences in lipid 
solubility and the existence of ionic transport do play a role in the uptake process, it is interesting to notice that the observed semilogarithmic relationship between absorption and $\mathrm{pH}$ (fig. 7) strongly supports the principal validity of the equation and thus of the $\mathrm{pH}$ partition hypothesis for the fatty acid absorption.

\section{Uptake against a concentration gradient}

The results showed fatty acid concentrations of the tissue fluid that greatly exceeded the medium concentration (fig. 4 and 6). It is unproven whether the fatty acids are in a free state within the tissue-fluid, but it seems likely, according to the experiments of Bloch et al (10) and Sallee, Wilson \& Dietschy (24). This observed accumulation is not, however, interpreted as an uptake really occurring against a concentration gradient, but rather as an indication in favour of the $\mathrm{pH}$ partition hypothesis. The fatty acid accumulation in the tissue obviously increased with increasing lipophility (increasing chainlength and decreasing medium-pH). Exact values for intra- and intercellular $\mathrm{pH}$ are not available. A value of 7.0 is, though, generally expected, taking into consideration the possibility that it may vary between different cell-compartments (25). An accumulation even at a medium-pH of 7.0 did occur (fig. 5, compare also Bloch et al (10)), this can, however, be explained by a local acidification at the membrane surface due to the $\mathrm{H}^{+}$-secretion ("microclimate" according to Hogben et al. (3)) in the jejunum.

From the mentioned equation of Jacobs it can be calculated that - for a $\mathrm{pK}_{\mathrm{a}}$ of 4.8 and anticipating a $\mathrm{pH}$-value of 7.0 on the contraluminal side - a medium-pH of 6.7 will give $\frac{C_{1}}{C_{2}}=2$. Thus, theoretically, a pH-difference of only $0.3 \mathrm{pH}$-units will result in an accumulation with the fatty acid concentration in the tissue-fluid being twice as high as in the incubation-medium.

\section{Influence of the fatty acid concentration in the} medium

In a passive transport-system the absorption is proportional to the substrate concentration, but in the case of a carrier-mediated transport the percentage absorbed will decrease with increasing concentration due to saturation of the carrier.

The results of the experiments relating to the substrate concentration (fig. 8-10) showed a concentration-dependence of the fatty acid uptake which conformed to saturation kinetics. The calculated " $\mathrm{K}_{\mathrm{m}}$-values" seemed to indicate an increasing carrier-affinity with increasing fatty acid chain-length and decreasing medium- $\mathrm{pH}$, (tab. 3). However, as often mentioned in the literature (26) experimentally demonstrated "Michaelis-Mentenkinetics" have to be interpreted carefully and do not necessarily imply a carrier-mediated transport. In fact, a transport-mechanism based on non-ionic diffusion gives an alternative explanation for the saturation kinetics. Though the $\mathrm{pH}$ of the tissue is kept rather constant by effective buffer-systems (25), by increasing fatty acid concentrations the capacity of the regulation-mechanism eventually will become exhausted, and $\mathrm{pH}$ within the tissue-fluid will decrease (27). As a result of the reduced $\mathrm{pH}$-difference between both sides of the membrane the non-ionic fatty acids will sooner approach an equilibrium, and consequently limit the absorption process.

\section{Competitive inhibition}

A carrier-mediated transport is characterized by chemical specificity. Chemically closely related substances will compete for attachment at the carrier and therefore inhibit each other mutually.

No chemical specificity could be found for the transport of SCFA and MCFA (27). The described results (table 4) suggesting competitive inhibition for SCFA and MCFA, in fact again can be explained alternatively by the above mentioned exhaustion of the $\mathrm{pH}$-regulation capacity of the tissue. This view is supported by the fact that the degree of "inhibition" was about the same whether the fatty acid concentration was increased by the same or another acid, as became evident from a comparison of the results of the saturation experiments and those of table 4.

This interpretation of the inhibition-phenomena is further supported by the observation that the longer i.e. the faster diffusing - fatty acids appear to be stronger "inhibitors" than the shorter ones.

\section{Influence of inhibitors of "active" transport}

In order to study the effect of metabolic inhibitors 2.4-dinitrophenol-an uncoupler of oxidative phosphorylation-was used representatively. In accordance with other authors $(5,10)$ the results showed an effect on fatty acid uptake (tab. 5).

Hogben (28) has shown in vitro that inhibition of energyproviding processes blocks the $\mathrm{H}^{+}$-secretion of gastric mucosa. It seems likely that the obvious need for sufficient metabolic energy is related to the energy-requiring $\mathrm{H}^{+}$-secretion in the jejunal mucosa by which the tissue maintains a constant $\mathrm{pH}$, thus providing the necessary $\mathrm{pH}$-difference between both sides of the membrane to enable a continuous fatty acid diffusion.

Fatty acid uptake has also proven to be dependent on a sufficient sodium concentration in the medium (own unpublished results; (20)). However, the need for sodium seems to be of a different nature than for typically "actively" transported substances as the results (tab. 5) indicated that the inhibition of the "sodium pump" by ouabain had no effect on the uptake of propionic acid, whereas there was a marked inhibition of the control substance 3-oxymethyl glucose. An explanation for 
the need of sodium in the fatty acid transport process is probably found in the assumption that the secretion of hydrogen ions in the jejunal mucosa is accomplished by a hydrogen sodium exchange-mechanism (27).

In this connection it is interesting to mention divergent results concerning the effects of glucose and galactose on fatty acid uptake: Smyth \& Taylor (5) had observed an increased absorption on addition of glucose and an inhibition on addition of galactose. They interpreted their findings as a result of the need for energy within the tissue: glucose activates fatty acid transfer because it provides energy when it is metabolised, whereas galactose, - not being metabolised but actively transported -, even lowers the available energy-level. In the experiment of Smyth \& Taylor (5) an incubationtime of 90 min and a $\mathrm{pH}$ of 7.4 were used. In own experiments, using short incubation-times (4 min) and a $\mathrm{pH}$ of 5-5.5, there rather was seen an inhibiting effect of glucose and no effect of galactose on fatty acid uptake. This could be explained as a result of lactic acid production due to glucose metabolism. As the $\mathrm{pH}$ of the bulk phase was rather acid an increased acid production within the tissue tends to overstress the $\mathrm{pH}$ - regulation mechanism, thus limiting the fatty acid diffusion. As was to be expected, galactose had no effect, as it is not metabolised.

\section{Concluding remarks}

In the described experiments fatty acid concentration was determined in the total tissue-fluid, without distinguishing between intracellular fluid and subepithelial extracellular fluid. At least in experiments with low medium-pH-values an accumulation of fatty acids also within the intracellular fluid is probable. The apparent fatty acid transport against the concentration gradient seems mainly to be due to non-ionic diffusion.

Fatty acid uptake can, in fact, be considered an "active" transport-mechanism in as much as it needs metabolic energy for the $\mathrm{pH}$-regulation-mechanism. It probably is not, however, an "active" transport in the sense of a specific, sodium dependent carrier-mediated transport-system, like e.g. that of many monosaccharides and amino acids, for which substrate saturation, chemical specificity and competitive inhibition are characteristic.

\section{References}

1. Brodic. B. B. \& Hogben, C. A. M., (1957). J. Pharm. (London) 9, 345-380.

2. Schanker, L. S., Shore, P. A., Brodie, B. B. \& Hogben, C. A. M., (1957). J. Pharmacol. Exp. Ther. 120, 528-539.

3. Hogben, C. A. M., Tocco, D. J., Brodie, B. B. \& Schanker L. S., (1959). J. Pharmacol. Exp. Ther. 125, 275-282.

4. Johnston, J. M. \& Borgström, B., (1964). Biochim. Biophys. Acta 84, 412-423

5. Smyth, D. H. \& Taylor, C. B., (1958). J. Physiol. (London) $141,73-80$

6. Barry, R. J. C. \& Smyth, D. H., (1960). J. Physiol. 152, 4866.

7. Barry, R. J. C., Jackson, M. J., Smyth, D. H., (1966). J. Physiol. $185,667-683$.

8. Hogben, C. A. M., (1966). Gastroenterology 50, 51-55.

9. Dawson, A. M., Holdsworth, C. D. \& Webb, J., (1964). Proc. Soc. Exp. Biol. Med. 117, 97-100.

10. Bloch, R., Habcrich, F. J. \& Lorenz-Mcycr, H., (1972). Pflügers Arch. Physiol. 335, 198-212.

11. Agar, W. T., Hird, F. J. R., Sidhu, G. S., (1954). Biochim. Biophys. Acta 14. 80-92.

12. Semenza, G., (1969). Biochim. Biophys. Acta 173, 104-112

13. Wilson, T. H. \& Wiseman, G., (1954). J. Physiol. 123, 116 125.

14. Crane, R. K. \& Mandelstam, P., (1960). Biochim. Biophys. Acta 45, 460-476.

15. Wilson, F. A. \& Dictschy, J. M., (1974). Biochim. Biophys. Acta 363, 112-126.
16. Moe, H., (1955). Intern. Rev. Cytol. 4, 299-334.

17. Wilson, T. H. \& Kazyak, L., (1957). Biochim. Biophys. Acta 24, 124-132.

18. Gallagher, N. D. \& Playoust, M. R., (1969). Gastroenterology $57,9-18$.

19. Hoffman, N. E., (1970). Biochim. Biophys. Acta 196, 193-203.

20. Mishkin, S., Yalovsky, M. \& Kessler, J. I., (1971). Biochim. Biophys. Acta 225, 335-346.

21. Danielli, J. F., (1972), in Role of membrane in metabolic regulation (Mehlman, M. \& Hanson, R. eds.) Academic Press, New York.

22. Smyth, D. H. \& Whittam, R., (1967). Brit. Med. Bull. 23, 231-235.

23. Jacobs, M. H., (1940). Cold. Spring Harb. Symp. Quant. Biol. 8, 30-39.

24. Sallee, V. L., Wilson, F. A. \& Dietschy, J. M., (1972). J. Lipid Res. 13, 184-192.

25. Waddell, W. J. \& Bates, R. G., (1969). Physiol. Rev. 49, $285-325$.

26. Neame, K. D. \& Richards, T. G., (1972). Elementary kinetics of membxane carrier transport Blackwell Scientific Publications, Oxford.

27. Jackson, M. J.,(1975). Intestinal Absorption (Smyth, D. H., ed.) Plenum Press, London, (in press).

28. Hogben, C. A. M., (1960). Fed. Proc. 19, 864-869.

29. Jackson, M. J. \& Smyth, D. H., (1968). Nature (London) $219,388-389$.
Dr. Christine Naupert und

Prof. Dr. K. Rommel

Abt. Klinische Chemie

Universität Ulm

$79 \mathrm{UIm} /$ Donau

Steinhövelstr. 9 